\title{
Sulitnya Menemukan Obat Baru di Indonesia
}

\author{
Hairunnisa Hairunnisa \\ Program Studi Magister Farmasi, Fakultas Farmasi, Universitas Padjadjaran, Sumedang 45363 \\ email: syahrunazzami@gmail.com \\ (Submit 24/3/2019, Revisi 14/7/2019, Diterima 15/7/2019)
}

\begin{abstract}
Abstrak
Penemuan dan pengembangan obat terus menerus dilakukan untuk terus menghasilkan produk-produk yang bermanfaat di dunia kesehatan. Target obat biasanya berupa sel, protein, gen, ataupun biofarmasetik. Uji pra klinis dan uji klinis merupakan tahapan yang penting dalam penemuan dan pengembangan obat. Dalam artikel komentar ini dibahas terkait kemungkinan pengembangan obat baru di Indonesia dari berbagai aspek seperti sumber bahan baku, target obat, penelitian, dan biaya.
\end{abstract}

Kata kunci : obat baru, penemuan, uji praklinis, uji klinis

\section{Outline}

- Pendahuluan

- Proses penemuan obat baru

- Penentuan target atau sasaran tempat kerja obat

- Skrining senyawa obat

- Optimasi senyawa secara komputasi Formulasi senyawa obat

- Uji pra klinis dan uji klinis Izin edar obat baru

- Kesimpulan

- Daftar Pustaka

\section{Pendahuluan}

Sejarah penemuan obat sebenarnya dimulai dari hal yang tidak disengaja ketika Alexander Fleming sedang melakukan penelitian terhadap bakteri Staphylococcus. Ketika penelitiannya telah selesai, ia meninggalkan laboratorium dan lupa membersihkan cawan petri yang berisi bakteri tersebut. Sehingga, saat kembali untuk melanjutkan penelitian Fleming melihat cawan petri yang berisikan bakteri terkontaminasi oleh jamur yang menyebabkan perkembangan bakteri menjadi terhambat, jamur itu adalah jamur Penicillium chrysogenum.

Penelitian pun terus dilanjutkan untuk mengetahui senyawa yang terkandung pada jamur Penicillium chrysogenum sehingga lahirlah antibiotik pertama yang disebut Penisilin. 
Sejarah penisilin menceritakan sesuatu ketidaksengajaan yang bermanfaat, meskipun harus melalui tahapan proses yang panjang dan tidak mudah. Menurut definisinya obat adalah bahan atau paduan bahan, termasuk produk biologi yang digunakan untuk mempengaruhi atau menyelidiki sistem fisiologi atau keadaan patologi dalam rangka penetapan diagnosis, pencegahan, penyembuhan, pemulihan, peningkatan kesehatan dan kontrasepsi, untuk manusia. ${ }^{1}$

\section{Proses penemuan obat baru}

Penemuan dan pengembangan obat terus menerus dilakukan untuk terus menghasilkan produk produk yang bermanfaat di dunia kesehatan.

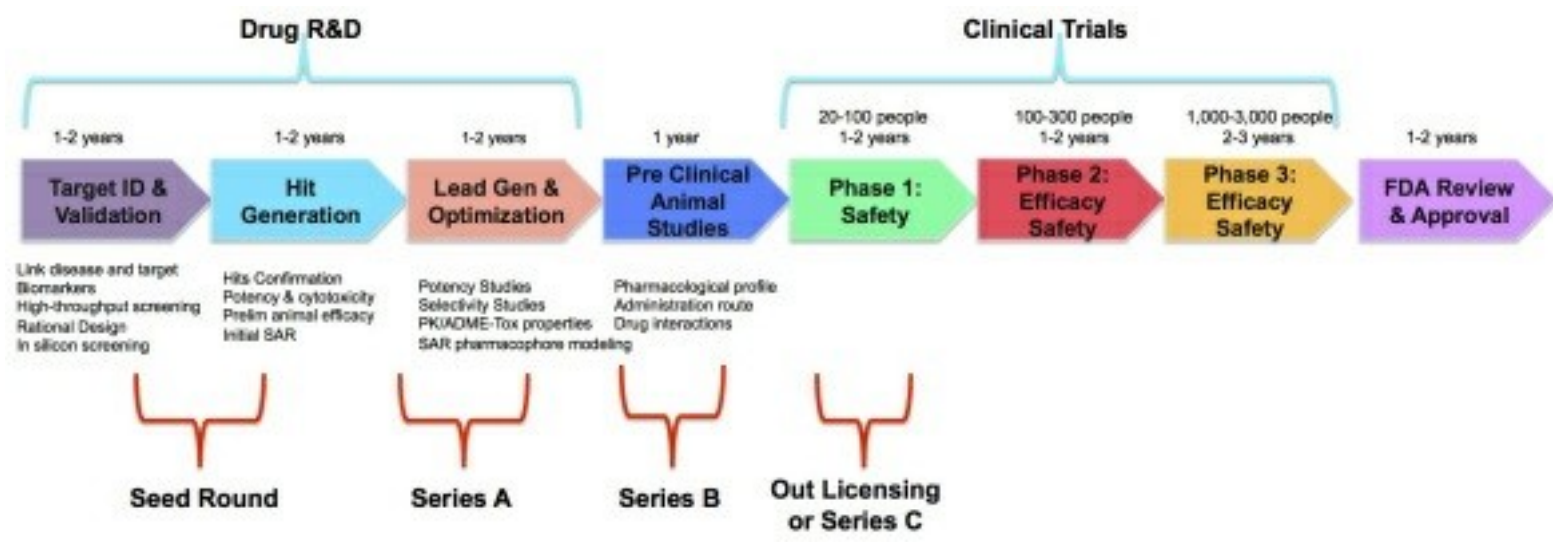

Gambar 1. Proses Penemuan Obat Baru di Amerika Serikat

Tahapan yang dilakukan dalam penemuan dan pengembangan obat yaitu penseleksian target kerja obat, dilanjutkan dengan penentuan senyawa kemudian memprediksi kinerja senyawa berdasarkan struktur kimia (in silico), lalu dilanjutkan dengan pengujian pra klinis (in vitro dan in vivo) dan uji klinis untuk melihat respon obat terhadap tubuh manusia. Jika tahapan pengujian telah dilalui tahapan registrasi merupakan tahapan akhir untuk mendapatkan ijin edar dari pihak yang berwenang demi memperkuat pernyataan keamanan obat.

\section{Penentuan target atau sasaran tempat kerja obat}

Target obat biasanya berupa sel, protein, gen, ataupun biofarmasetik. Suatu target obat yang baik adalah target yang dapat menyeleksi beberapa kandidat molekul obat yang secara aktif dapat berinteraksi dengan target sehingga dapat digunakan sebagai obat yang efektif. ${ }^{2}$

Target obat untuk sediaan inhalasi umumnya adalah sistem pernapasan. Asma, PPOK, dan infeksi seperti tuberkulosis merupakan penyakit yang biasanya diberikan obat dalam bentuk inhalasi.

Tuberkulosis (TB) adalah suatu penyakit infeksi yang disebabkan oleh Mycobacterium tuberculosis sistemis di paru paru yang biasanya merupakan lokasi infeksi primer. 
Tuberkulosis dapat juga ditularkan ke bagian tubuh lainnya, terutama meningen, ginjal, tulang, dan nodus limfe. Mycobacterium tuberculosis merupakan prokariotik dengan benteng pertahanan yang kuat berupa dinding sel yang terdiri dari empat lapisan, yaitu phospholipid bilayer, peptidoglikan, arabinogalaktin, dan asam mikolat (mycolic acids).

\section{Skrining senyawa obat}

Skrining dilakukan untuk mengidentifikasi senyawa yang akan bekerja di target yang akan diobati. Penentuan senyawa ini dapat dilakukan dengan melakukan sintesis ataupun isolasi dari senyawa yang dimaksud. Hasil dari prosedur skrining ini disebut sebagai senyawa utama, yaitu merupakan kandidat utama untuk obat baru. ${ }^{3}$

\section{Optimasi senyawa secara komputasi}

Selanjutnya dilakukan pendekatan senyawa secara komputasi (in silico). Salah satunya yaitu penambatan molekul secara kimiawi. ${ }^{4}$ Pendekatan secara kimiawi komputasi dapat digunakan untuk memprediksi aktivitas struktur, interaksi yang terjadi antara struktur dengan molekul target atau antara sesama molekul obat.

\section{Formulasi senyawa obat}

Setelah mendapatkan senyawa obat yang sesuai, dibuat rancangan formula agar obat dapat dihantarkan dengan baik pada target obat. Sediaan tablet merupakan sediaan yang paling populer karena mudah dalam penanganannya dan cenderung lebih ekonomis.

Namun kini mulai bermunculan teknologi penghantaran obat tertarget dalam bentuk inhalasi khususnya untuk gangguan saluran pernapasan. Contohnya rifampin. Dari awal ditemukan, rifampin diformulasikan menjadi tablet. Kemudian seiring dengan perkembangan teknologi, rifampin kini telah mulai diformulasikan menjadi bentuk inhalasi. Berdasarkan penelitian Mizoe dkk bahwa sediaan rifampin-mannitol efektif dalam menghantarkan obat ke paru-paru. ${ }^{5}$

\section{Uji pra klinis dan uji klinis}

Uji pra klinis dan uji klinis merupakan tahapan yang penting dalam penemuan dan pengembangan obat. Uji praklinik merupakan persyaratan uji untuk kandidat obat, dari uji ini diperoleh informasi tentang efek farmakologi, profil farmakokinetik dan toksisitas dari kandidat obat. Pada mulanya yang dilakukan pada uji praklinik adalah pengujian ikatan obat pada reseptor dengan kultur sel terisolasi atau organ terisolasi (in vitro), selanjutnya pengujian praklinis dilakukan pada hewan utuh (in vivo). ${ }^{6}$

Hewan yang biasa digunakan adalah hewan dengan galur tertentu dari mencit, tikus, kelinci, marmot, hamster, anjing, hewan-hewan ini sangat berjasa bagi pengembangan obat. Hanya dengan menggunakan hewan utuh dapat diketahui apakah obat menimbulkan efek toksik pada dosis pengobatan atau obat tersebut aman digunakan. 
Untuk itu pengujian secara in vitro dilakukan untuk menentukan khasiat obat Pada pengujian in vitro kita dapat memprediksi afinitas dan selektifitas dari zat yang dimaksudkan untuk bekerja dengan reseptor target, dapat juga terlihat mekanisme aksi dari senyawa tersebut. Selanjutnya pengujian In vivo dilakukan menggunakan hewan uji.

Tujuan utama dari eksperimen in vivo adalah untuk mendapatkan pengetahuan tentang sistem biologis dilihat dari perilaku hewan uji. Uji toksisitas juga dapat terlihat pada saat pengujian menggunakan hewan uji, untuk melihat adanya gambaran reaksi biokimia, fisiologik dan patologik pada manusia terhadap suatu sediaan uji.

Hasil uji toksisitas tidak dapat digunakan secara mutlak untuk membuktikan keamanan suatu bahan/ sediaan pada manusia, namun dapat memberikan petunjuk adanya toksisitas relatif dan membantu identifikasi efek toksik bila terjadi pemaparan pada manusia.

Faktor-faktor yang menentukan hasil uji toksisitas secara in vivo dapat dipercaya adalah pemilihan spesies hewan uji, galur dan jumlah hewan, cara pemberian sediaan uji, pemilihan dosis uji, efek samping sediaan uji, teknik dan prosedur pengujian termasuk cara penanganan hewan selama percobaan. ${ }^{7}$

Setelah kandidat obat dinyatakan mempunyai kemanfaatan dan aman pada hewan percobaan maka selanjutnya dilakukan uji klinik (diuji pada manusia). Uji pada manusia harus diteliti dulu kelayakannya oleh komite etik. Uji klinik terdiri dari 4 fase yaitu :

1. Fase I, kandidat obat diuji pada sukarelawan sehat 25-50 orang untuk mengetahui apakah sifat yang diamati pada hewan percobaan juga terlihat pada manusia. Pada fase ini ditentukan hubungan dosis dengan efek yang ditimbulkannya dan profil farmakokinetik obat pada manusia.

2. Fase II, kandidat obat diuji pada pasien tertentu 100-200 orang, diamati efikasi pada penyakit yang diobati. obat memiliki efek yang potensial dengan efek samping rendah atau tidak toksik. Pada fase ini mulai dilakukan pengembangan dan uji stabilitas bentuk sediaan obat.

3. Fase III melibatkan kelompok besar pasien sekitar ribuan orang, di sini obat yang dikembangkan dibandingkan efek dan keamanannya terhadap obat pembanding yang sudah diketahui. Keputusan diberikan oleh badan pengatur nasional, di Indonesia keputusan hasil pengujian dikeluarkan oleh Badan Pengawas Obat dan Makanan, dengam melampirkan data dokumen uji praklinik dan klinik yang sesuai dengan indikasi yang diajukan, efikasi dan keamanannya harus sudah ditentukan dari bentuk produknya (tablet, kapsul dll.) yang telah memenuhi persyaratan produk melalui kontrol kualitas. $^{7}$

4. Fase IV, setelah obat dipasarkan masih dilakukan studi pasca pemasaran ( post marketing surveillance) yang diamati pada pasien dengan berbagai kondisi, berbagai usia dan ras, studi ini dilakukan dalam jangka waktu lama untuk melihat nilai terapeutik dan pengalaman jangka panjang dalam menggunakan obat. Setelah hasil studi fase IV dievaluasi masih memungkinkan obat ditarik dari perdagangan jika membahayakan. 
Sebagai gambaran, dari 10 ribu senyawa kandidat obat yang diteliti, hanya 1 senyawa obat yang berhasil dipasarkan dan sampai ke pasien.

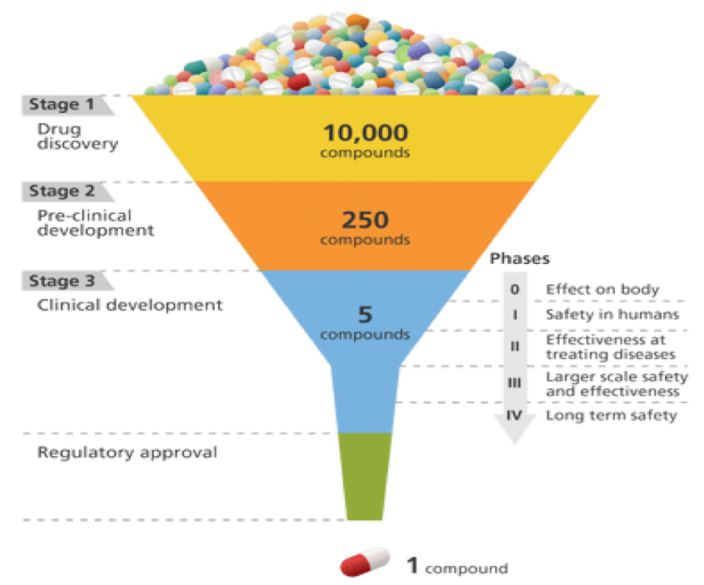

\section{Izin edar obat baru}

Gambar 2. Dari 10 ribu kandidat obat, hanya 1 yang sukses

Obat yang akan diedarkan di wilayah Indonesia wajib memiliki Izin Edar. ${ }^{8}$ Setelah melakukan serangkaian pengujian penemuan dan pengembangan obat. Selanjutnya dilakukan registrasi demi mendukung keamanan obat yang akan dikembangkan dengan mendapatkan nomor registrasi sehingga keamanan konsumen lebih terjaga.

Pasal 106 Undang-Undang Nomor 36 Tahun 2009 tentang Kesehatan menyatakan bahwa Sediaan farmasi dan alat kesehatan hanya dapat diedarkan setelah mendapat izin edar. Penandaan dan informasi sediaan farmasi dan alat kesehatan harus memenuhi persyaratan objektivitas dan kelengkapan serta tidak menyesatkan.

Industri farmasi sebagai pelaku usaha dalam menjalankan usahanya harus mempunyai kewajiban Memberikan informasi yang benar, jelas dan jujur mengenai kondisi dan jaminan dari obat yang di produksi serta memberi penjelasan penggunaan, Menjamin mutu obat yang diproduksi dan diperdagangkan berdasarkan ketentuan standar mutu yang berlaku. Nah semua proses ini semata mata demi menjamin keamanan produk yang akan digunakan oleh masyarakat. ${ }^{9}$

Dari sisi biaya, dengan proses yang panjang, menemukan suatu obat baru sangatlah mahal dan perlu investasi jangka panjang, tidak heran umumnya industri farmasi di Indonesia jarang melakukan riset sampai ditemukan obat baru hingga dipasarkan, tidak heran impor bahan baku farmasi masih diatas angka $90 \%$.

\section{Kesimpulan}

Penemuan dan pengembangan obat terus menerus dilakukan untuk terus menghasilkan produk produk yang bermanfaat di dunia kesehatan. Tahapan yang dilakukan dalam penemuan dan pengembangan obat cukup panjang hingga diedarkan di tingkat konsumen. Selain itu, faktor biaya menjadi kendala industri farmasi di Indonesia melakukan riset sampai ditemukan obat baru hingga dipasarkan, tidak heran impor bahan baku farmasi masih diatas angka $90 \%$. 


\section{Daftar Pustaka}

Supardi S, Sasanti HR, Raharni. Kajian Peraturan Perundang-Undangan Tentang Pemberian Informasi Obat dan Obat Tradisional di Indonesia. J Kefarmasian Indones. 2012;2:20-27.

Radji M. Pendekatan Farmakogenomik Dalam Pengembangan Obat Baru. Pharm Sci Res. 2017;2(1):1-11. doi:10.7454/psr.v2i1.3379

Bertram G. Katzung, MD P. Basic \& Clinical Pharmacology. Twelfth Ed. (Susan B. Masters P, Anthony J. Trevor P, eds.).; 2012.

Ruswanto. MOLECULAR DOCKING EMPAT TURUNAN ISONICOTINOHYDRAZIDE PADA MYCOBACTERIUM TUBERCULOSIS ENOYL-ACYL CARRIER PROTEIN REDUCTASE (InhA). J Kesehat Bakti Tunas Husada. 2015;13:213-227.

Ruswanto R, Nofianti T, Mardianingrum R, Lestari T. Desain dan Studi In Silico Senyawa Turunan Kuwanon-H sebagai Kandidat Obat Anti-HIV. J Kim Val. 2018;4(1):57-66. doi:10.15408/jkv.v4i1.6867

Wulansari AN. ALTERNATIF CANTIGI UNGU (Vaccinium varingiaefolium) SEBAGAI ANTIOKSIDAN ALAMI : REVIEW. 2018;16:222-230.

BPOM R. PERATURAN KEPALA BADAN PENGAWAS OBAT DAN MAKANAN REPUBLIK INDONESIA NOMOR 7 TAHUN 2014 TENTANG PEDOMAN UJI TOKSISITA NONKLINIK SECARA IN VIVO. In: ; 2014:561-565.

BPOM. Peraturan Kepala Badan Pengawas Obat Dan Makanan Republik Indonesia Nomor 24 Tahun 2017 Tentang Kriteria Dan Tata Laksana Registrasi Obat. Bpom. 2017:116. doi:10.1017/CBO9781107415324.004

Wulansari C, Firdaus, Nuryanti A. Tanggung Jawab Instansi Terkait Terhadap Peredaran Obat Impor Tradisional Kaitannya Dengan Perlindungan Konsumen. 2014;3(5):1-35. 